\title{
Pengembangan Instrumen Sukuk Dalam Medukung Pembangunan Infratruktur
}

\author{
Anik*, Iin Emy Prastiwi \\ Program Studi Ekonomi Islam, STIE AAS Surakarta, Indonesia \\ *Email korenpondensi: karjunianik@yahoo.co.id
}

Recieved 07-11-2017 | Revised 14-11-2017| Accepted 29-11-2017

\begin{abstract}
Abstrak
Pendanaan pembangunan menjadi hal utama dalam pembangunan infrastruktur berbagai negara. Dikutip dari berita ekonomi bahwa Pemerintah akan membiayai beberapa pembangunan infrastruktur jalan dan jembatan dengan menggunakan surat berharga syariah negara (SBSN) alias sukuk di 2016. Mengapa perkembangan sukuk cukup lambat, padahal mayoritas pendukuk Indonesia adalah muslim dan bagaimana strategi pengembangan sukuk sebagai salah satu produk pasar modal syariah sehingga berperan signifikan dalam pembangunan infrastruktur di Indonesia. Metode penelitian untuk memberikan gambaran secara jelas mulai dari manfaat sukuk dan peran sukuk terhadap pembangunan infrastruktur mengunakan metode kualitatif deskriptif. Hasil kajian menunjukkan bahwa proses perencanaan pengembangan sukuk dengan top-down dan bottom-up bertujuan menyelaraskan program-program untuk menjamin adanya sinergi/konvergensi dari semua kegiatan pemerintah dan masyarakat dalam optimalisasi pengembangan sukuk. Strategi perencanaan secara Top-Down adalah penerbitan "Sukuk Wakaf" sebagai Upaya Peningkatan Market Share Sukuk. Sebagai produk baru, sukuk wakaf masih menghadapi beberapa kendala. Diantaranya dibutuhkan peraturan yang jelas dan khusus mengatur tentang sukuk wakaf. Serta Membuat landasan syariah tentang penerbitan sukuk wakaf. Strategi kedua adalah membentuk Tim APS (Akselerasi Pengembangan Sukuk). Tim ini sebagai wadah atau organisasi yang dibentuk untuk mengakomodir percepatan dan pertumbuhan obligasi syariah atau sukuk. Sedangkan strategi perencanaan secara Top-Down adalah membentuk forum EKPPOS (Edukasi, Komunikasi, Pemasaran dan Pengembangan Obligasi Syariah). Strategi kedua adalah memberikan praktikum Pasar Modal Syariah di lingkungan kampus.
\end{abstract}

Kata Kunci: Sukuk, Pembangunan Infrastruktur, Top-Down, Bottom Up

Saran sitasi: Anik, A., \& Prastiwi, I. (2017). Pengembangan Instrumen Sukuk Dalam Medukung Pembangunan Infratruktur. Jurnal Ilmiah Ekonomi Islam, 3(03), 173-180. doi:http://dx.doi.org/$\underline{10.29040 / j i e i . v 3 i 03.129}$

DOI: http://dx.doi.org/10.29040/jiei.v3i03.129

\section{Pendahuluan}

Pemerintah Indoneisa menerapkan kebijakan anggaran ekspansif yang menjadikan pengeluaran belanja Negara lebih besar dari pada pendapatan Negara. Kebijakan tersebut diterapkan karena pemerintah mendorong pembangunan infrastruktur yang berkelanjutan dan inklusif. Untuk mendukung rencana pemerintah dalam pembangunan infrastruktur maka pemerintah menerbitkan Surat Berharga Syariah Negara (SBSN) yang berupa sukuk. Fatah (2011), di Indonesia pasar keuangan syari'ah termasuk sukuk tumbuh dengan cepat, meskipun porsinya dibandingkan pasar konvensional masih relatif sangat kecil. Untuk keperluan pengembangan basis sumber pembiayaan anggaran Negara dan 


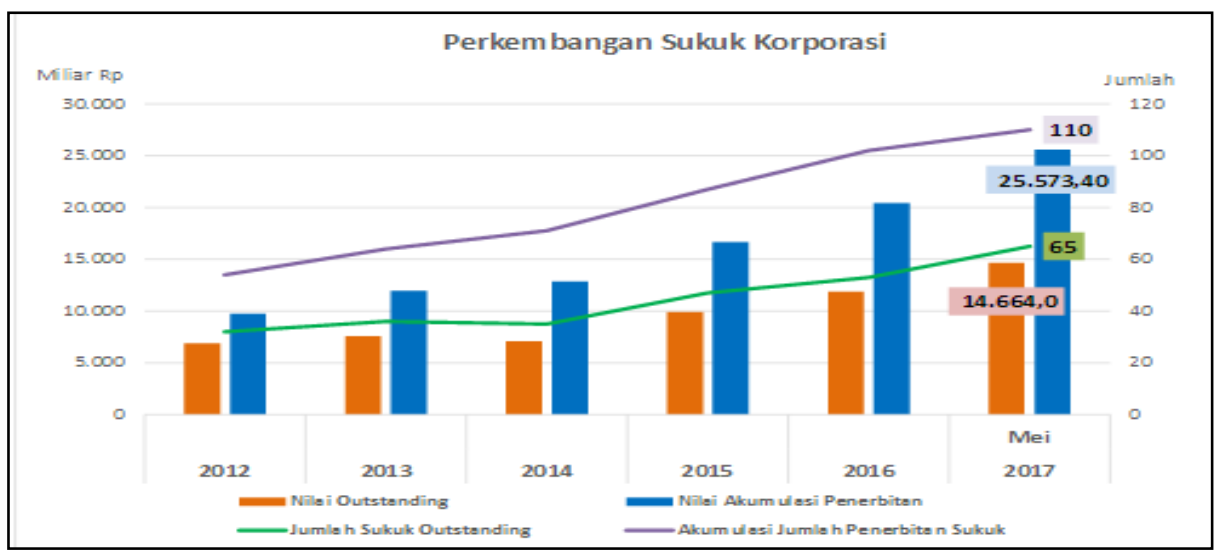

Gambar 1. Perkembangan Sukuk di Indonesia

Sumber: Otoritas Jasa Keuangan, (2017)

dalam rangka pengembangan pasar keuangan syari'ah dalam negeri, pemerintah telah mengesahkan RUU tentang Surat Berharga Syari'ah Negara (SBSN).

Abubakar, et al. (2012), Pembangunan infrastruktur merupakan kebutuhan mendesak bagi percepatan dan perluasan pembanguan ekonomi Indonesia. Untuk mewujudkan visi indonesia sebagaimana tertuang dalam master plan perencanaan dan perluasan ekonomi indonesia (MP3EI), yakni transformasi ekonomi indonesia menjadi Negara maju yang diakui oleh komunitas dunia melalui petumbuhan ekonomi yang tinggi, inklusif dan berkesinambungan. Datuk (2014), Sukuk Negara berperan dalam mengamankan Kebutuhan Pembiayaan APBN dengan biaya minimal pada tingkat resiko terkendali, sehingga menjaga kesinambungan fiskal. Pembiayaan APBN melalui utang merupakan bagian dari pengelolaan keuangan negara yang lazim dilakukan oleh suatu Negara. Utang merupakan instrumen utama pembiayaan APBN untuk menutupi defisit APBN, dan untuk membayar kembali utang yang jatuh tempo (debt financing). Refinancing dilakukan dengan term and conditions (biaya dan resiko) utang baru yang lebih baik.

Respati (2016), melalui Project Based Sukuk (PBS), pemerintah memperoleh alternatif sumber pembiayaan khusus untuk membiayai proyek infrastruktur. Sejak diterbitkan pertama kali pada 2012 total penerbitan PBS telah mencapai Rp 81,17 triliun, dari total penerbitan sukuk negara yang sebesar Rp 380,21 triliun. Jenis proyek yang dapat dibiayai oleh sukuk negara mencakup proyek pembangunan infrastruktur (sektor energi, telekomunikasi, perhubungan, pertanian, industri manufaktur dan perumahan rakyat), penyediaan pelayanan umum, pemberdayaan industri dalam negeri, dan pembangunan lain sesuai dengan kebijakan strategis pemerintah. Selanjutnya Dewan Syariah Nasional Majelis Ulama Indonesia (DSN-MUI), juga telah mengeluarkan sebuah keputusan terkait kriteria proyek yang sesuai dengan prinsip syariah, sehingga bisa dibiayai oleh sukuk negara. Keputusan tersebut tertuang dalam Ketetapan DSN MUI Nomor 01/DSN-MUI/III/2012 tentang Kriteria Proyek Sesuai dengan Prinsip Syariah. Ketetapan DSN MUI tersebut menyatakan bahwa proyek bisa digunakan sebagai dasar penerbitan dan/atau dibiayai melalui penerbitan Surat Berharga Syariah Negara sepanjang tidak bertentangan dengan prinsip syariah dan peraturan perundangundangan yang berlaku. Proyek tersebut pun harus memenuhi sejumlah kriteria persyaratan.

Berdasarkan Gambar 1, dapat diketahui bahwa perkembangan sukuk mengalami peningkatan dari tahun ke tahun. Pertumbuhan nilai outstanding dari tahun 2012 samai dengan tahun 2017 mengalami peningkatan yang sangat signifikan. Dari permasalahan diatas maka timbul pertanyaan untuk diteliti lebi kanjut, mengapa perkembangan sukuk cukup lambat, padahal mayoritas pendukuk Indonesia adalah muslim dan bagaimana strategi pengembangan 
sukuk sebagai salah satu produk pasar modal syariah sehingga berperan signifikan dalam pembangunan infrastruktur di Indonesia.

\section{Kajian Pustaka}

Menurut Rivai et al. (2012), Surat Berharga Syariah Negara (SBSN) adalah surat berharga negara yang diterbitkan berdasarkan prinsip syariah, merupakan sumber dana potensial untuk pembangunan. SBSN diterbitkan dan dikelola pada investasi berbasis syariah dengan konsep bagi hasil (mudharabah). Oleh karena itu memerlukan underlying asset sebagai dasar penerbitan dan diterbitkan dengan suatu akad. Penerbitan SBSN saat ini ditujukan untuk membiayai defisit APBN termasuk membiayai pembangunan proyek. Underlying asset adalah asset yang dijadikan sebagai objek atau dasar transaksi dalam kaitannya dengan penerbitan sukuk. Tanpa adanya underlying asset surat berharga ynag diterbitkan akan sama dengan sifatnya sebagai instrumen utang. Sesuai dengan undang-undang tentang SBSN Underlying asset pada SBSN berupa objek pembiayaan SBSN atau barang milik Negara (BMN) yang bernilai ekonomis.

Dalam UU No 19/2008 dikatakan bahwa underlying aset adalah aset SBSN, dimana aset SBSN adalah obyek pembiayaan SBSN dan/atau barang milik negara (BMN) yang memiliki nilai ekonomis, berupa tanah dan/atau bangunan maupun selain tanah dan/atau bangunan, yang dalam rangka penernitan SBSN dijadikan sebagai dasar penerbitan SBSN. Adapun yang dimaksud barang milik negara adalah semua barang yang dibeli atau diperoleh atas beban anggaran pendapatan dan belanja negara (APBN) atau berasal dari perolehan lain yang sah. Tujuan utama pemerintah menerbitkan sukuk negara adalah untuk membiayai APBN, termasuk mambiayai pembangunan proyek.

Instrument-insrtumen syariah yang dikeluarkan oleh badan usaha atau lembaga keuangan selalu diawali dengan adanya Fatwa dari Dewan Syariah Nasional (DSN) yang menjadi dasar hukum keabsahan suatu produk. Hanya saja yang menjadi pertanyaan adalah apakah Fatwa DSN tersebut dapat dijadikan sebagai sebuah dasar hukum yang mengikat, mengingat Fatwa DSN tidak termasuk dalam Tata Urutan PerundangUndangan Republik Indonesia sebagaimana diatur dalam Undang-Undang Nomor 10 Tahun 2004 Tentang Pembentukan Peraturan Perundang -Undangan.

Menurut Sutedi (2008), Sukuk merupakan peluang untuk mengundang para investor muslim dan nonmuslim untuk mau terlibat berinvestasi di tanah air. Dengan demikian, sukuk dapat dimanfaatkan untuk membangun perekonomian bangsa dan menciptakan kesejahteraaan masyarakat. Fakta selama ini menunjukan bahwa pasar akan sangan responsive terhadap penerbitan sukuk. Hampir semua sukuk yang dikeluarkan, diserap habis oleh pasar, dan bahkan pada beberapa kasus sampai menimbulkan kelebihan permintaan, apabila sukuk tersebut diterbitkan oleh Negara.

\section{Metode Penelitian}

Metode penelitian ini mengunakan metode kualitatif deskriptif, pengunaan metode tersebut diharapkan dapat memberi gambaran secara jelas mulai dari manfaat sukuk dan peran sukuk terhadap pembangunan infrastruktur. Adapun data sekuder dalam penelitian diambil dari instansi pemerintahan terkait, yaitu: Kemenkeu, melalui www.kemenkeu.go.id serta Direktorat Pemberdayaa Wakaf Kementerian Agama RI, serta untuk memperkaya pembahasan, maka publikasi-publikasi ilmiah lainnya juga dimanfaatkan.

\section{Hasil dan Pembahasan}

Nasrullah (2015), dalam pengembangan infrastruktur, sukuk dapat menjadi instrument yang tepat, hal tersebut dikarenakan sukuk sebagai surat utang Negara (SUN), untuk memperoleh dana pembangunan infrastruktur. Penerbitan sukuk mengharuskan adanya underlying asset yang jelas untuk menjaga kepercayaan pihak yang membeli sukuk. Sukuk sebagai instrument memperoleh dana pembangunan infrastruktur lebih tepat karena mengguna- 
kan akad bagi hasil yang lebih kebal terhadap risiko nilai tukar. Datuk (2014), sukuk lebih unggul dari pada pinjaman luar negeri, karena risiko sukuk lebih rendah dari berbagai aspek. Harapannya sukuk dapat menjadi sumber dana pembangunan infrastuktur yang lebih dominan disbanding pinjaman luar negeri.

Dalam pembahasan ini penulis akan menjelaskan dan menguraikan pengembangan sukuk secara Top-Down dan Bottom-Up Planning. Secara hierarki, prosedur perencanaan itu dilakukan atas dasar prinsip Top-Down Planning, yaitu proses perencanaan yang dilakukan oleh pemimpin tertinggi suatu organisasi kemudian atas dasar keputusan tersebut dibuat suatu perencanaan di tingkat yang lebih rendah. Prinsip lainnya adalah lawan dari prinsip di atas yaitu Bottom-Up Planning yang merupakan perencanaan yang awalnya dilakukan di tingkat yang paling rendah dan selanjutnya disusun rencana organisasi di atasnya sampai dengan tingkat pusat atas dasar rencana dari bawah.

Strategi perencanaan dari atas ke bawah (Top Down) adalah pendekatan perencanaan yang menerapkan cara penjabaran rencana induk ke dalam rencana rinci. Rencana rinci yang berada di "bawah" adalah penjabaran rencana induk yang berada di "atas". Pendekatan perencanaan sektoral acapkali ditunjuk sebagai pendekatan perencanaan dari atas ke bawah, karena target yang ditentukan secara nasional dijabarkan ke dalam rencana kegiatan di berbagai daerah di seluruh Indonesia yang mengacu kepada pencapaian target nasional tersebut. Penulis menyusun strategi pengembangan susuk Top-Down dan Bottom-Up dengan mengacu pada salah satu Hadits Rasulullah SAW tentang mempertemukan 1 tujuan yaitu pengembangan sukuk, dicapai melalui 2 arah, yaitu melalui peran pemerintah dan masyarakat. Hadit tersebut adalah sebagai berikut:

Dari Abu Hurairah radhiyallahu 'anhu, ia berkata: Nabi Shalallahu 'alaihi wa sallam bersabda: "Allah Ta'ala berfirman:...Jika ia mendekat kepadaKu sejengkal maka Aku mendekat kepadanya sehasta. jika ia mendekat
kepadaKu sehasta maka Aku mendekat kepadanya sedepa. Jika ia datang kepadaKu dengan berjalan maka Aku datang kepadanya dengan berlari-lari kecil". (Hadits ditakhrij oleh Bukhari).

\subsection{Strategi Pengembangan Sukuk Top-} Down: Penerbitan "Sukuk Wakaf" sebagai Upaya Peningkatan Market Share Sukuk

Menurut Yudha (2017), Kabar terbaru adalah penerbitan sukuk wakaf oleh pemerintah. Model sukuk wakaf diluncurkan oleh Bank Indonesia bekerjasama dengan Kementerian BUMN, Kementerian Keuangan, Badan Wakaf Indonesia (BWI), dan perwakilan BUMN meluncurkan model sukuk linked waqaf yang merupakan inovasi untuk mengoptimalkan pemanfaatan aset Wakaf dengan Sukuk. Yasinta (2016), yang memungkinkan potensi penerbitan sukuk wakaf adalah BUMN karena BUMN juga bergerak dibidang pembangunan infrastruktur. Respati (2016), BUMN yang menerbitkan sukuk dan menawarkannya ke investor, setelah masuk dana dari penjualan sukuk lalu dana akan digunakan untuk membangun infrastruktur bersama dengan kontraktor. Ketika aset jadi, maka akan disewakan. Hasilnya kemudian akan dibagi ke nadzhir maupun pemilik sukuk. Di akhir periode aset akan dikembalikan ke nadzhir.

Berdasarkan data tanah wakaf pada Tabel 1, menunjukkan ada 4,359 miliar $\mathrm{m}^{2}$ tersebar diseluruh Indonesia. Dari data tersebut sangat potensial untuk dilakukan pembangunanpembangunan infrastruktur yang bermanfaat bagi masyarakat. Selama ini pembangunan tanah wakaf kita kenal untuk pembangunan masjid, pondok pesantren, kuburan atau hanya sebatas sarana ibadah saja. Padahal dengan tanah wakaf maupun dana wakaf produktif, bisa digunakan untuk membangun infrastruktur yang bermanfaat untuk publik dan produktif sebagai lahan bisnis seperti rumah sakit, apartemen, gedung perkantoran, pusat perbelanjaan dan sebagainya. Keuntungannya digunakan sebesar-besarnya untuk kesejahteraan umat, misalnya untuk beasiswa anak-anak yang tidak mampu, sekolah 


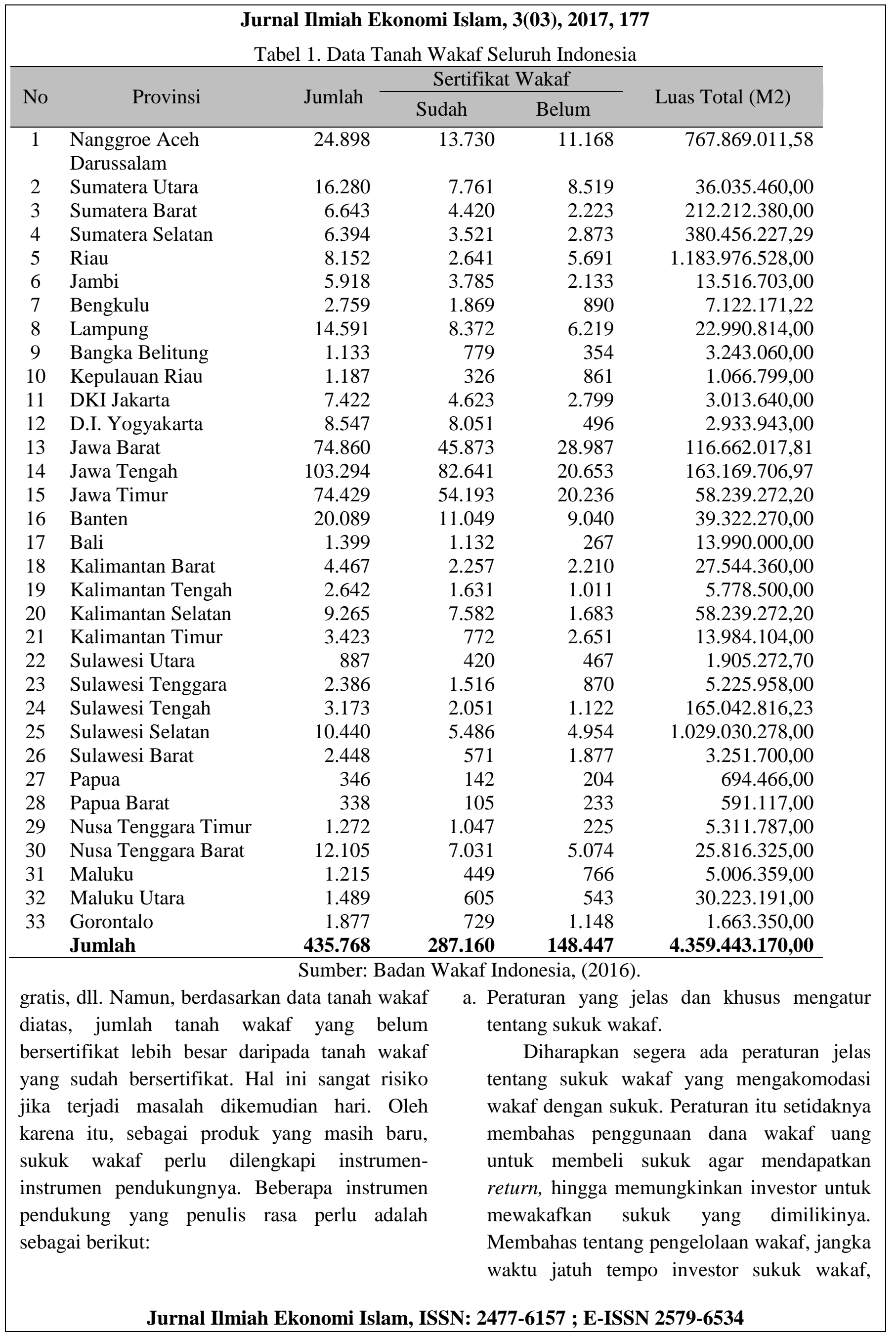


apabila ada wanprestasi dan ketentuanketentuan lain yang dibutuhkan. Peraturan ini menjadi perlindungan hukum yang lebih jelas dan spesifik tentang pihak-pihak yang berkepentingan dalam sukuk wakaf ini.

b. Sertifikasi tanah wakaf bagi tanah wakaf yang belum bersertifikat

Wakaf yang merupakan sumbangan harta dari masyarakat untuk kepentingan umum dan juga kesejahteraan umum mestinya didukung penuh oleh pemerintah, baik dalam hal regulasi maupun sertifikasi. Sebenarnya sertifikasi tanah wakaf yang belum bersertifikat sudah diusahakan oleh Badan Wakaf Indonesia, namun ada beberapa yang tersendat. Keterlibatan pemerintah seperti Otoritas Jasa Keuangan (OJK), Bank Indonesia (BI), dan Badan Pertanahan Nasional (BPN) diperlukan dalam sertifikasi tanah wakaf yang berkendala.

c. Membuat landasan syariah tentang penerbitan sukuk wakaf

Menurut Respati (2016), penerbitan sukuk dapat menggunakan aset wakaf sebagai underlying-nya selama memenuhi beberapa prinsip; Pertama, sepanjang pengelolaannya bisa untuk mempertahankan keawetan harta wakaf itu. Kedua, selama penerbitan sukuk akan memberi manfaat baik bagi kepentingan publik. Ketiga, selama tidak akan memberikan keuntungan tertentu kepada orang atau pihak tertentu.

\subsection{Strategi Pengembangan Sukuk Bottom-Up}

\section{a. Sukuk "Goes to Campus"}

Menurut Respati (2016), Sosialisasi Surat Berharga Syariah Negara (SBSN) pernah diselenggarakan oleh Kementerian Keuangan Direktorat Jendral Pengelolaan Pembiayaan dan Resiko bekerjasama dengan Universitas Halu Oleo. Dimana kita bisa menyebarkan informasi dan minat masyarakat tentang kepemilikan sukuk dan Surat Berharga Syariah Negara (SBSN). Selain dapat mengetahui bagaimana cara memasyarakatkan sukuk negara, dengan sosialisasi Surat Berharga Syariah Negara (SBSN) ini juga mahasiswa dapat menambah ilmu dan pengetahuan,khususnya pada mahasiswa jurusan ekonomi maupun yang terkait bidang ilmunya dengan Sukuk Negara maupun Surat Berharga Syariah Negara (SBSN). Menurut Humas UHO (2015), Pemberian praktikum pasar modal syariah dilingkungan kampus dilakukan oleh akademisi dan praktisi serta mahasiswa. Mahasiswa mengenal dan berinvestasi secara langsung dalam pasar modal syariah. Dengan memberikan praktikum pasar modal syariah praktikum ini bisa melibatkan institusi-institusi terkait. Praktikum bisa dalam bentuk metode pembelajaran praktik operasional sekaligus mahasiswa menjadi investor sukuk.

\section{b. Membentuk Forum EKPPOS (Edukasi, Komunikasi, Pemasaran dan Pengembangan Obligasi Syariah)}

Pengamat pasar modal Budi Hikmat, menilai bahwa sosialisasi dan edukasi kepada masyarakat terhadap produk investasi di pasar modal berbasis syariah masih perlu terus ditingkatkan (ANTARA, 2016). Menurut Budi Hikmat dalam "Talk Show Festival Pasar Modal Syariah 2016, masih banyak masyarakat yang bertanya halalharam megenai investasi di pasar modal syariah, padahal sudah jelas labelnya syariah. Dalam mengenalkan sukuk sebagai salah satu produk pasar modal syariah, kepada masyarakat perlu adanya suatu forum yang berfungsi sebagai forum untuk edukasi, komunikasi dan sosialisasi tentang sukuk. Forum ini bisa beranggotakan akademisi, praktisi, investor, asosiasi pengusaha atau universitas-universitas serta pihak-pihak yang berkepentingan. Forum ini yang bertujuan untuk meningkatkan market share obligasi syariah dan mempermudah komunikasi dua arah antara pemerintah dengan pelaku obligasi syariah Dengan adanya Forum EKPPOS (Edukasi, Komunikasi, Pemasaran dan Pengembangan Obligasi Syariah) diharapkan dapat meningkatkan market share obligasi syariah.

\subsection{Sinergi Strategi Top-Down dan Bottom $U p$}

Proses perencanaan pengembangan sukuk dengan top-down dan bottom-up bertujuan menyelaraskan program-program untuk menjamin adanya sinergi/konvergensi dari semua kegiatan pemerintah dan masyarakat dalam optima- 
lisasi pengembangan sukuk. Pertemuan antara perencanaan yang bersifat top-down dan bottomup diwadahi dalam musyawarah perencanaan. Dimana perencanaan makro yang dirancang oleh pemerintah pusat disempurnakan dengan memperhatikan masukan dari semua stakeholders dan selanjutnya digunakan sebagai pedoman.

\section{Kesimpulan}

Perlu adanya sinergi perencanaan pengembangan sukuk di Indonesia. Sinergi tersebut melalui strategi pengembangan sukuk Top-Down dan Bottom Up. Perencanaan pengembangan sukuk secara Top-Down dilakukan oleh atasan atau pemerintah. Strategi perencanaan secara Top-Down, yang diantaranya adalah Penerbitan "Sukuk Wakaf" sebagai Upaya Peningkatan Market Share Sukuk. Sebagai produk baru, sukuk wakaf masih menghadapi beberapa kendala. Diantaranya dibutuhkan peraturan yang jelas dan khusus mengatur tentang sukuk wakaf. Serta Membuat landasan syariah tentang penerbitan sukuk wakaf dan membentuk Tim APS (Akselerasi Pengembangan Sukuk). Tim ini sebagai wadah atau organisasi yang dibentuk untuk mengakomodir percepatan dan partumbuhan obligasi syariah atau sukuk. Sedangkan strategi perencanaan secara Top-Down adalah membentuk Forum EKPPOS (Edukasi, Komunikasi, Pemasaran dan Pengembangan Obligasi Syariah). Forum ini bisa beranggotakan akademisi, praktisi, investor, asosiasi pengusaha atau universitas-universitas serta pihak-pihak yang berkepentingan. Forum ini bertujuan meningkatkan regulasi dan edukasi oleh pemerintah dengan kerjasama intensif antara akademisi, praktisi, lembaga terkait dan masyarakat untuk membangun kesadaran akan pentingnya pasar modal syariah khususnya sukuk sebagai bagian dari penggerak sektor riil perekonomian Indonesia.

\section{Ucapan Terimakasih}

Penulis ingin menyampaikan ucapan terimakasih kepada STIE AAS Surakarta yang telah mendukung selesainya penelitian ini.

\section{Daftar Pustaka}

Abubakar, L., Nyulistyowati, Handayani, T., Sukmadilaga, Andri, F. (2012). Sukuk sebagai Alternatif Pembiayaan Infrastruktur dalam rangka Perluasan dan Percepatan Pembangunan. Universitas Padjadjaran

ANTARA, (2016) Pengamat: tingkatkan sosialisasi-edukasi pasar modal syariah. https://www.antaranews.com/berita/552848/ pengamat-tingkatkan-sosialisasi-edukasipasar-modal-syariah, diakses pada tanggal 31 Juli 2017 pukul 14:00

Badan Wakaf Indonesia (2016). Data Tanah Wakaf Seluruh Indonesia. http://bwi.or.id/index.php/in/tentang-wakaf/data-wakaf/data-wakaf-tanah.html diakses pada tanggal 31 Juli 2017 pukul 15:19

Datuk, B. (2014). Sukuk Dimensi Baru Pembiayaan Pemerintah untuk Pertumbuhan Ekonomi. Jurnal Riset Akuntansi dan Bisnis, Vol.4. No.1. Fakultas Ekonomi Universitas Sumatra Utara

Fatah, D.F. (2011). Perkembangan Obligasi Syari'ah (Sukuk) Di Indonesia: Analisis Peluang dan Tantangan. Jurnal Innovatio, Vol. X No.2.

Humas UHO. (2015). Sukuk Negara "Goes To Campus" "Sosialisasi Surat Berharga Syariah Negara (SBSN)". diakses pada tanggal 31 Juli 2017 pukul 22:05

Nasrullah, A. (2015). Studi Surat Berharga Negara: Analisis Komparatif SukukNegara dengan Obligasi Negara dalam pembiayaan Defisit APBN. Jurnal Lentera: Kajian Keagamaan, Keilmuan dan Teknologi, Vol. 1 No. 2. Nganjuk: Sekolah Tinggi Agama Islam Miftahul 'Ula.

Otoritas Jasa Keuangan (2017). Statistik Sukuk Mei 2017. http://www.ojk.go.id/id/kanal/syariah/data-dan-statistik/data-produkobligasi-syariah/Documents/Pages/StatistikSukuk---Mei-2017/Statistik\%20Sukuk\%20Mei\%202017.pdf diakses pada tanggal 17 Juli 2017 pukul 21:35

Respati, Y. (2016). Ini Syarat Penerbitan Sukuk dengan Underlying Aset Wakaf. diaksess pada tanggal 31 Juli 2017 pukul 18:33

Rivai, Veithzal dkk. (2012). Islamic Banking and Finance. Yogyakarta: BPFE. 
Jurnal Ilmiah Ekonomi Islam, 3(03), 2017, 180

Sutedi. (2008). Aspek Hukum Obligasi dan Sukuk. Yudha, S.K. (2017). Sukuk Berbasis Wakaf Jakarta: Sinar Grafika

Yasinta, Veronika. (2016). BUMN Berptensi Diluncurkan. diakses pada tanggal 31 Juli 2017 pukul 14:17

Jalankan Sukuk Berbasis Wakaf. diakses

pada tanggal 31 Juli 2017 pukul 14:37 